\title{
Neil Price
}

\section{The Viking Way: Magic and Mind in Late Iron Age Scandinavia}

Oxbow Books 2019

398 pages

ISBN 978-1-84217-260-5

\section{Review by Colleen Batey}

This much revised second edition of The Viking Way more than replaces the multi award-winning first edition. That edition provided a unique insight into the aspects of the Viking World which are less understood, less studied but increasingly revealing themselves through discoveries at cult sites, Lejre and Tiso for example. In a world where oral histories were transmitted, potentially embellished and which brought together a deep understanding of the natural and spiritual environment, the Viking World holds a pre-eminent position. The role of sorcery and the societal role of sorcerers themselves is laid out in this study, with mysterious artefacts given meaning, in some cases in combination with an archaeological investigation into the secret world of witch craft and its accoutrements; this provides considerable enrichment to this era. As a research tool this work is invaluable, wellproduced and indeed very well-priced. In these days when hard copies are not the first option for the student (or indeed wider) market, this must be an exception. Within these pages (acknowledgements to the second edition) readers and fellow scholars can see the debt of gratitude Price expresses to an extended list of colleagues for their discussions since the 2002 edition. To see such full acknowledgement of the assistance of others is indeed rare in modern scholarship.

The volume is divided into eight main chapters. Chapter one concerns 'Different Vikings? Toward a cognitive archaeology of the later Iron Age', and wrestles with the diffuse concept of cognition and the materiality of 
textual sources. These concepts are often obscure and certainly hard to relate to the archaeological record; this is an excellent place to commence our education in broadening our own approaches to the data many of us work with regularly from this period. Getting to grips with early mindsets is a minefield and this chapter assists us by steering a safe course - at least as a guide for the development of further approaches. Chapter two concerns 'Problems and paradigms in the study of Old Norse sorcery', providing detail of Norse my thologies and the role of the seiðr. Importantly it introduces the concept of 'the double world': interconnected existences portrayed in life as well as Old Norse sources. Chapter three is entitled simply 'Seiðr' and provides a very full consideration of the performers, the performance itself and the embeddedness of this within Viking society. The discussion is wide-ranging and through several good illustrations (particularly noteworthy in this chapter), ensures this will be a significant contribution to discussion. Chapter four provides a hugely important consideration on the Noaidevuohta and the Sami religion. These near-neighbours of the Vikings to the north have been considered by a number of authors within Scandinavia, and it useful to see this being brought together here. As a non-Scandinavian scholar, I am more used to considering this relationship as an economic one using the words of Othere and the major site of Borg of Lofoten. That is however only a small part of the reality, when reliance on the natural world and the changing seasons dictating reindeer movements would inevitably have brought a much deeper inter-relationship and understanding of these actors in this landscape; the unseen but accepted forces would be a simple integration into daily life. Chapter five brings a study of 'Circumpolar religion and the question of Old Norse shamanism', and is a most useful comparative discussion. The final three chapters look at more overarching themes: chapter six considers the 'Supernatural empowerment of aggression' and a few points within this are picked up in this review below; chapter seven is simply entitled 'The Viking Way', perhaps curiously separated from the following final chapter eight on 'Magic and Mind'. Throughout the discussions are superbly illustrated with items which are from widely dispersed sources and include several newly prepared illustrations (of particular note are the fine reconstruction drawings by Pórhallur Práinsson).

Perhaps unsurprisingly there is a focus on the material from Birka and its important ongoing re-assessment, but other familiar major sites such as Klinta, Fyrkat, Hedeby, Lejre are brought into the debate. The bringing together of the physical evidence for possible staffs which may be related to sorcery practices (e.g. Figure 3.83 and catalogue in chapter three) is helpful, showing a considerable concentration in mid Sweden and Sogn og Fjordane, Norway, primarily from burial contexts. In Denmark slightly fewer finds are recorded of staffs, but burial contexts predominate. Price notes two lo- 
cations in Scandinavia for ritual deposits containing staffs, Lilla Ullevi in Uppland and Hemdrup, Jylland. Outside Scandinavia, the numbers are very limited in this category of evidence, with just one or two noted from Finland, Iceland, Isle of Man, Orkney and Ireland in the form of burial finds of staffs without shaft mounts (staffs with expanded handles) and two from Russia of staffs with shaft mounts. It is clear even from simple examination of this data that the full range of example forms (five in all) are to be seen in Scandinavia itself, and much less variation elsewhere. I would assume this could at least in part be due to changes in religious practice following expansion in addition to preservation and recovery issues. Elsewhere in the assemblages identified as part of the Seiðr identity, the miniature chair pendants are notable (and usefully brought together in images supplied). Likewise, the full discussion about the role and portrayal of the Valkyries in literature and material culture in chapter six. This section combines particularly well the literary context with the archaeological context. A discussion of the wideranging literary sources concerning female warriors encompasses sources from the Byzantine world with those Ireland and the world of the Old Norse sagas. It incorporates very recent discussion concerning the female warrior grave from Birka (Bj. 58I) and the identification of similar rich warrior assemblages from female graves in Norwegian contexts. The identification and indeed recovery (commonly enhanced by metal-detecting discoveries) of small silver figurines, as from Hårby near Roskilde or the mount from Tissø, Sjaelland complement images known from picture stones, such as Lärbro III, Stora Hammars, Gotland and potentially the Oseberg tapestry in providing a visual element to this debate. A possible omission in the discussions seems to be a consideration of the materiality of Norse mythology - Thor's hammer pendants, whalebone plaques, and so forth which are present beyond Scandinavia and embrace earlier belief systems.

There can be no doubt that this revised edition is a considerable asset to the library shelves of all interested audiences. It is written in a most approachable manner and brings together very disparate sources as is the hallmark of Price's writing. The ability to span vast academic and physical landscapes in academic research is a gift not given to everyone and in this volume Neil Price shows why the earlier edition won so many plaudits. The quality of production, range of fine illustrative elements and keen, updated research will ensure this volume has a wide and long-lasting currency.

\section{References}

Price, N.S. 2002. The Viking Way: Religion and War in Late Iron Age Scandinavia. PhD thesis. Uppsala: Uppsala University. 